\title{
Hemoglobin Threshold for Blood Transfusion in a Pediatric Intensive Care Unit
}

\author{
Madhuradhar Chegondia Jun Sasaki ${ }^{a}$ André Raszynskia,b Balagangadhar R. Totapally ${ }^{a, b}$ \\ a Division of Critical Care Medicine and Nicklaus Children's Hospital (Formerly Miami Children's Hospital), Miami, FL, USA; \\ ${ }^{b}$ Herberth Wertheim College of Medicine, Florida International University, Miami, FL, USA
}

\section{Keywords}

Hemoglobin - Threshold · Packed red blood cell . Transfusion · Children · PICU

\section{Summary}

Objective: To evaluate the hemoglobin threshold for red cell transfusion in children admitted to a pediatric intensive care unit (PICU). Methods: Retrospective chart review study. Tertiary care PICU. Critically ill pediatric patients requiring blood transfusion. No intervention. Results: We analyzed the charts of all children between 1 month and 21 years of age who received packed red blood cell (PRBC) transfusions during a 2-year period. The target patients were identified from our blood bank database. For analysis, the patients were subdivided into four groups: acute blood loss (postsurgically, trauma, or acute gastrointestinal bleeding from other causes), hematologic (hematologic malignancies, bone marrow suppression, hemolytic anemia, or sickle cell disease), unstable $\left(\mathrm{FiO}_{2}>0.6\right.$ and/or on inotropic support), and stable groups. We also compared the pre-transfusion hemoglobin threshold in all unstable patients with that of all stable patients. A total of 571 transfusion episodes in 284 patients were analyzed. $28 \%(n=160)$ of transfusions were administered to patients in the acute blood loss group, $36 \%$ ( $n=206$ ) to hematologic patients, $17 \%$ ( $n=99)$ to unstable patients, and $18 \%(n=106)$ to stable patients. The mean pre-transfusion hemoglobin ( \pm SD) in all children as well as in the acute blood loss, hematologic, unstable and stable groups was $7.3 \pm 1.20,7.83 \pm$ $1.32,6.97 \pm 1.31,7.96 \pm 1.37,7.31 \pm 1.09 \mathrm{~g} / \mathrm{dl}$, respectively. The transfusion threshold for acute blood loss and unstable groups was higher compared to hematologic and stable groups ( $p<0.001$; ANOVA with multiple comparisons). The mean pre-transfusion hemoglobin thresh- old for stable and unstable patients among all groups was $7.3 \pm 1.3$ and $7.9 \pm 1.3(p<0.0001)$, respectively. The observed mortality rate was higher among children who received transfusion compared to other children admitted to PICU. Conclusion: The hemoglobin threshold for transfusion varied according to clinical conditions. Overall, the hemoglobin threshold for transfusion was $7.3 \pm$ $1.20 \mathrm{~g} / \mathrm{dl}$.

(c) 2016 S. Karger GmbH, Freiburg

\section{Introduction}

Transfusion of blood products, especially of packed red blood cells (PRBCs), is an important aspect of care in critically ill children. Clinical indications for blood transfusions in children and adults are similar, but hemoglobin threshold, transfusion volume in relation to body weight, and infusion rates are not well delineated.

Children admitted to a pediatric intensive care unit (PICU) have an increased risk of developing anemia due to the underlying etiology and illness severity, iatrogenic blood loss, hemodilution, poor nutrition, and blunted bone marrow response [1-4]. A large, prospective, multicenter, observational study [5] reported an incidence rate of $74 \%$ of anemia in PICU patients; $33 \%$ of patients had anemia on admission. Studies from Kenya have shown a significantly increased mortality in children with a hemoglobin level of less than $5 \mathrm{~g} / \mathrm{dl}$ and a decreased mortality after transfusion [6-8]. Transfusion of PRBCs is common in the PICU. The overall incidence of transfusion has been reported as $17 \%$ of all PICU patients and as up to $50 \%$ in children with a stay longer than 48 hours [9]. However, PRBC transfusions may result in multiple adverse effects including increased mortality, transfusion reactions, volume overload, infections, and immunosuppression [10].

\section{KARGER}

Fax +497614520714

\section{(c) 2016 S. Karger GmbH, Freiburg}

$1660-3796 / 16 / 0434-0297 \$ 39.50 / 0$ 
In order to decrease the risk of transfusion complications, the American Association of Blood Banks recommends a restrictive transfusion threshold of 7-8 g/dl in hospitalized and stable patients and suggests adhering to a restrictive strategy in hospitalized patients with preexisting cardiovascular disease. A hemoglobin threshold of $8 \mathrm{~g} / \mathrm{dl}$ or less is recommended for transfusion if patients are symptomatic [11].

There is no agreed hemoglobin level for PRBC transfusions in children admitted to a PICU. The threshold for transfusion may vary with underlying diagnosis and physiologic stability. In a retrospective survey of five PICUs in the USA [12], nearly 55\% of all PICU patients with pre-transfusion hemoglobin levels of less than $9 \mathrm{~g} / \mathrm{dl}$ received one or more PRBC transfusions. Despite the publication of the Transfusion Requirements in Critical Care in 1999 [13], there remains great variability in the pediatric critical care specialists practice with respect to the threshold hemoglobin level for PRBC transfusion [14]. An overly restrictive transfusion strategy may increase the risk of tissue hypoxia and a too liberal transfusion strategy may lead to an increased incidence of adverse effects. A survey of pediatric critical care specialists from Canada and Europe regarding PRBC transfusion practices revealed a wide range of hemoglobin transfusion thresholds $(7-13 \mathrm{gm} / \mathrm{dl})$ and of PRBC transfusion volumes $[14,15]$. In addition, the threshold hemoglobin levels for transfusions varied with the underlying medical or surgical conditions [15]. Our study is the first to compare the PRBC transfusion thresholds among four groups of PICU patients with different clinical conditions.

The aim of our study was to evaluate the hemoglobin threshold for red cell transfusion among four clinical groups in children admitted to a PICU.

\section{Material and Methods}

Our tertiary care PICU with 28 beds available, has on average 1,600 admissions per year and cares for all critically ill children, except for those after cardiac surgery. After obtaining institutional review board approval, the charts of all children who were admitted to our PICU during a 2-year-period and who received $\mathrm{PRBC}$ transfusions were retrieved. The target patient population data were identified and retrieved from our blood bank database. Any blood transfusions outside of the PICU (e.g. operating room, emergency room, medical and surgical floor) were not included. We excluded patients on ECMO and hemodialysis and patients who received an exchange transfusion.

Patients' personal identifiers (including unique patient characteristics) were removed from the data prior to analysis. For analysis, patients were subdivided into four groups: acute blood loss, hematologic, unstable, and stable groups. The acute blood loss group included patients who received transfusions after surgery or for overt internal or external bleeding. The hematologic group included patients with Hemoglobinopathy (mainly sickle cell disease), leukemia, lymphoma, solid tumors, bone marrow suppression, post bone marrow transplantation, and patients who were receiving chemotherapy. The unstable group included children with $\mathrm{FiO}_{2}$ requirement over 0.6 and patients who were receiving inotropic support and were not assignable to acute blood loss or hematologic groups. The stable group included patients who did not meet the criteria of the other groups. In a separate analysis, all unstable patients (any child with $\mathrm{FiO}_{2}$ requirement above 0.6 and/or reception of inotropic support irrespective of the underlying condition) were compared with all stable patients irrespective of the cause of anemia.
Each child's pre- and post-transfusion clinical variables, diagnosis, and demographics (including age, sex, weight, length of stay, and mortality) were documented. Transfusion variables collected included pre-transfusion and post-transfusion hemoglobin concentrations and volume of PRBC infused. Each transfusion episode was counted in the total number of transfusions if the hemoglobin level was measured before the transfusion. Multiple transfusions with no pre-transfusion hemoglobin values were considered as a single transfusion episode.

\section{Statistical Analysis}

Descriptive data are presented as mean \pm SD for parametric continuous data, median \pm interquartile range (IQR) for nonparametric data. Nonparametric ANOVA with Bonferroni multiple comparison tests was used to compare the means of all variables in four groups. Mann-Whitney $U$ test was used to compare pre-transfusion hemoglobin levels in all stable versus all unstable groups. Chi-square or Fisher's exact test was used to analyze binary data. Paired t-test was used to compare pre- and post-transfusion hemoglobin values. A p value $<0.05$ was considered significant.

\section{Results}

A total of 571 transfusion episodes in 284 patients were analyzed. Nearly $9 \%$ of all patients admitted to our PICU received a transfusion. $28 \%(n=160)$ of transfusions were administered to patients in the acute blood loss group, 36\% ( $\mathrm{n}=206)$ to hematologic patients, $17 \%(\mathrm{n}=99)$ to unstable patients, and $18 \%(\mathrm{n}=106)$ to stable patients.

The mean age of our patient population was $6.98 \pm 6.78$ years. The mean age in the acute blood loss and hematological groups was significantly different from that in the unstable and stable groups (table 1). The median PICU length of stay of all clinical groups was 22 days (IQR 10-45 days). The median PICU length of stay of the acute blood loss and hematological groups was significantly different compared to that of the unstable and stable groups $(\mathrm{p}<0.001)$ (table 1).

\section{Pre-Transfusion Hemoglobin}

The mean pre-transfusion hemoglobin value of our study population was $7.3 \pm 1.20 \mathrm{~g} / \mathrm{dl}$. The mean pre-transfusion hemoglobin for acute blood loss patients was $7.83 \pm 1.32 \mathrm{~g} / \mathrm{dl}$, for hematologic patients $6.97 \pm 1.31 \mathrm{~g} / \mathrm{dl}$, for unstable patients $7.96 \pm 1.37 \mathrm{~g} / \mathrm{dl}$, and for stable patients $7.31 \pm 1.09 \mathrm{~g} / \mathrm{dl}$. The mean pre-transfusion hemoglobin values in patients with acute blood loss and unstable patients were significantly higher than those of hematological and stable patients $(\mathrm{p}<0.05)$ (table 1). The mean pre-transfusion hemoglobin thresholds for all stable and all unstable patients were $7.3 \pm 1.3$ and $7.9 \pm 1.3$, respectively $(\mathrm{p}<0.0001)$. The numbers of transfusion episodes below $7 \mathrm{~g} / \mathrm{dl}$ and above $8 \mathrm{~g} / \mathrm{dl}$ were $37(37 / 160=23.1 \%)$ and 62 $(62 / 160=38.7 \%)$ in the acute blood loss group, $75(75 / 206=36.4 \%)$ and $29(29 / 206=14 \%)$ in the hematologic group, for patients 17 $(17 / 99=17.2 \%)$ and $41(41 / 99=41.4 \%)$ in the unstable group, and $35(35 / 106=33 \%)$ and $16(16 / 106=15.1 \%)$ in the stable group.

\section{Volume of PRBC}

The mean PRBC volume transfused for all patients was $11.52 \pm$ $9.94 \mathrm{ml} / \mathrm{kg}$. In acute blood loss patients, the mean PRBC volume 
Table 1. Demographic, hematologic, and transfusion variables in all children and children in various groups

\begin{tabular}{|c|c|c|c|c|c|c|}
\hline & All children & Acute blood loss & Hematologic & Unstable & Stable & $P$ value \\
\hline Number of children & 284 & 110 & 72 & 46 & 56 & \\
\hline Number of transfusions & 571 & 160 & 206 & 99 & 106 & \\
\hline Male, \% & 56.69 & 40.99 & 22.98 & 13.66 & 17.39 & \\
\hline Mean age, years & $6.98 \pm 6.78$ & $8.85 \pm 6.76^{\star}$ & $9 \pm 6.82^{*}$ & $3.35 \pm 5.05$ & $3.62 \pm 5.34$ & $<0.001$ \\
\hline Median length of stay, days (range) & $22(10-45)$ & $12(6-30)^{*}$ & $17.5(9.75-33.2)^{*}$ & $43(23.5-95)$ & $38.5(20-64)$ & $<0.001$ \\
\hline \multicolumn{6}{|l|}{ Pre-transfusion $\mathrm{Hb}, \mathrm{g} / \mathrm{dl}$} & $<0.001$ \\
\hline Mean \pm SD & $7.3 \pm 1.20$ & $7.83 \pm 1.32^{\star *}$ & $6.97 \pm 1.31$ & $7.96 \pm 1.37^{\star *}$ & $7.31 \pm 1.09$ & \\
\hline Min./max. & $2.4 / 12.4$ & $3.4 / 11.8$ & $2.4 / 10.3$ & $3.7 / 12.4$ & $4.6 / 10.2$ & \\
\hline Mean PRBC transfusion volume, $\mathrm{ml} / \mathrm{kg}$ & $11.52 \pm 9.94$ & $13.08 \pm 11.34^{\star * \star}$ & $9.79 \pm 9.23^{\star * *}$ & $12.05 \pm 7.05$ & $12.10 \pm 11.13$ & $<0.05$ \\
\hline Mean \pm SD & $9.83 \pm 1.97$ & $10.31 \pm 1.59$ & $9.04 \pm 1.73^{* * * *}$ & $10.39 \pm 1.80$ & $10.11 \pm 1.67$ & \\
\hline Min./max. & $4.4 / 7.1$ & $7.1 / 14.8$ & $4.4 / 14.3$ & $6.7 / 15.6$ & $6.1 / 13.6$ & \\
\hline $\begin{array}{l}{ }^{*} \text { Acute blood loss and hematologic group } \\
{ }^{\star *} \text { Acute blood loss and unstable groups } \\
{ }^{* *} \text { Acute blood loss group different from } \\
{ }_{* * * *} \text { Hematologic group different from ot }\end{array}$ & $\begin{array}{l}\text { ent from unst } \\
\text { from hemato } \\
\text { ologic group. } \\
\text { ups. }\end{array}$ & $\begin{array}{l}\text { and stable groups. } \\
\text { and stable groups. }\end{array}$ & & & & \\
\hline
\end{tabular}

transfused was $13.08 \pm 11.34 \mathrm{ml} / \mathrm{kg}$, while it was $9.79 \pm 9.23 \mathrm{ml} / \mathrm{kg}$ in hematological patients $(\mathrm{p}<0.05)$ (table 1$)$.

\section{Post-Transfusion Hemoglobin}

After transfusion, the mean hemoglobin concentration increased from $7.3 \pm 1.20$ to $9.83 \pm 1.97 \mathrm{~g} / \mathrm{dl}$ in all patients $(\mathrm{p}<0.001$; paired t-test). The post-transfusion hemoglobin was lower in the hematologic group compared to other groups $(\mathrm{p}<0.05)$ (table 1). The mean post-transfusion hemoglobin thresholds of stable and unstable patients among all groups were $9.7 \pm 1.8$ and $10.3 \pm 1.7$ $(\mathrm{p}<0.0001)$, respectively.

\section{Mortality Rate}

The mortality rate in the 284 transfused patients was $6.69 \%$ ( $\mathrm{n}=19$ ), with 4 in the acute blood loss, 5 in the hematologic, and 10 in the unstable group. As expected, the mortality was different among the four groups, with the highest mortality among unstable patients $(21.73 \%)$ and no mortality among stable patients ( $<<0.001$; chi-square test with Yates correction) (table 1). The mortality among those who did not receive any transfusion was $1.4 \%(\mathrm{p}<0.001$; OR 5.6 (2.6-12.4); Fisher's exact test).

\section{Discussion}

The mean hemoglobin threshold for transfusion in our unit was $7.3 \mathrm{~g} / \mathrm{dl}$ and differed according to the underlying clinical condition group. It was higher for acute blood loss and unstable patients compared to hematologic and stable patients. Our threshold hemoglobin values for transfusion were similar to those of published data for stable patients [16] and post-surgical critically ill children
[17]. There is limited data from clinical trials comparing the outcomes with restrictive and liberal transfusion protocols. Data from clinical trials on adults have shown improved patient outcomes with a restrictive transfusion strategy. A meta-analysis review of adult patients [18] was able to identify 10 randomized clinical trials where different PRBC transfusion triggers were analyzed with appropriate methodology. The transfusion thresholds evaluated in these trials were between 7 and $10 \mathrm{~g} / \mathrm{dl}$, and the mortality was one fifth lower (RR 0.80; 95\% CI 0.63-1.02) with restrictive transfusion regimens.

A multicenter randomized clinical trial [19] studied liberal versus restrictive transfusion strategies in 100 preterm infants and showed that the restrictive red cell transfusion group had a higher risk of intraparenchymal brain hemorrhage, periventricular leukomalacia, and apnea. Another clinical trial [20] in 451 premature infants showed that the mortality or severe morbidity rate was $2.6 \%$ higher in the restrictive group compared to the liberal transfusion strategy group, but the difference was not significant. The Transfusion Stategies for Patients in Pediatric Intensive Care Units (TRIPICU) study [16] found that in 637 stable patients in PICUs a transfusion threshold of $7 \mathrm{~g} / \mathrm{dl}$ rather than a liberal threshold of 9.5 $\mathrm{g} / \mathrm{dl}$ reduced transfusion requirements by $44 \%(0.9 \pm 2.6$ vs. $1.7 \pm$ 2.2 units/patient; $\mathrm{p}<0.001)$. Although there were no differences in mortality or multiorgan dysfunction rate between the two groups, the TRIPICU study [16] recommended a restrictive transfusion strategy in clinically stable patients in PICUs. This study does not address the transfusion threshold specifically for unstable children and children with hemolytic anemia and active bleeding. In a recent study on transfusion practice changes in PICUs over a decade and a significant decline in overall transfusions from $10.5 \%$ to $6.8 \%$ [21] was found. 
In a further analysis [17], PRBC transfusion thresholds in postsurgical PICU patients were studied by examining a subgroup of 124 postoperative patients of the original TRIPICU study patients. The study found similar outcomes compared to the overall TRIPICU study population, and a transfusion threshold of $7 \mathrm{~g} / \mathrm{dl}$ for stable post-surgical patients in PICUs was recommended. The threshold hemoglobin value for the acute blood loss group in our study was $7.8 \mathrm{~g} / \mathrm{dl}$. The acute blood loss group in our study mainly included patients who had experienced active bleeding either after surgery or from gastrointestinal tract. We included all actively bleeding and post-surgical patients irrespective of hemodynamic stability. The British Society of Hematology [22] also suggested a postoperative hemoglobin level of $7 \mathrm{~g} / \mathrm{dl}$ as transfusion threshold in both children and adults with stable postoperative cardiac function.

Another subgroup analysis of septic patients enrolled in the TRIPICU study [23] found no evidence of an increased risk of adverse outcome when comparing restrictive and liberal transfusion strategies. The data suggested that a hemoglobin level of $7 \mathrm{~g} / \mathrm{dl}$ may be safe for stable septic patients in PICUs. A recent literature review on PRBC transfusion in PICU patients [24] showed that a threshold hemoglobin level above $7 \mathrm{~g} / \mathrm{dl}$ does not yield improved outcomes; and several smaller studies suggested an increased risk of morbidity and mortality in PICU patients exposed to blood transfusions.

In our study we allocated all children who received transfusion into four groups. As expected, unstable patients, defined as patients requiring $60 \%$ of $\mathrm{O}_{2}$ or more and/or were on vasoactive medications, received transfusions at a higher threshold level (7.96 \pm 1.37 $\mathrm{g} / \mathrm{dl})$. In addition, patients in the acute blood loss group also received blood transfusion at a higher threshold value $(7.83 \pm 1.32$ $\mathrm{g} / \mathrm{dl}$ ). Most of the post-surgical children requiring transfusions were children after craniofacial or spinal surgery. Thresholds for transfusion in these patients are in general set by the surgical teams in our hospital. As discussed in the methodology, the present study did not include children after cardiovascular surgery.

In summary, the hemoglobin threshold for transfusion varied according to the clinical condition in our PICU. Overall, the hemoglobin threshold for transfusion in our PICU was $7.3 \pm 1.2 \mathrm{~g} / \mathrm{dl}$. The threshold hemoglobin level for transfusion was higher for children with acute blood loss and unstable children. The mortality was higher among children who required blood transfusion.

\section{Study Limitations}

This study is a retrospective single-center study. The findings from one center may not apply to other centers with different patient populations. The mortality data obtained allows us only to state an association between the severity of disease, transfusion probability and mortality, but no causal relation that blood transfusions are an independent risk factor of mortality can be assumed.

\section{Acknowledgements}

We thank Dr. S. Melnick, director of the blood bank at Nicklaus Children's Hospital (formerly Miami Children's Hospital) for providing the data.

\section{Disclosure Statement}

None.

\section{References}

1 Shander A: Anemia in the critically ill. Crit Care Clin 2004;20:159-178.

2 Scharte M, Fink MP: Red blood cell physiology in critical illness. Crit Care Clin 2003;31(12 suppl):S651-657.

3 Krafte-Jacobs B, Levetown ML, Bray GL, Ruttimann UE, Pollack MM: Erythropoietin response to critical illness. Crit Care Clin 1994;22:821-826.

4 Rogiers P, Zhang H, Leeman M, Nagler J, Neels H, Mélot C, Vincent JL: Erythropoietin response is blunted in critically ill patients. Intensive Care Med 1997;23:159-162.

5 Bateman ST, Lacroix J, Boven K, Forbes P, Barton R, Thomas NJ, Jacobs B, Markovitz B, Goldstein B, Hanson JH, Li HA, Randolph AG; Pediatric Acute Lung Injury and Sepsis Investigators Network: Anemia, blood loss, and blood transfusions in North American children in the intensive care unit. Am J Respir Crit Care Med 2008;178:26-33.

6 English M, Ahmed M, Ngando C, Berkley J, Ross A: Blood transfusion for severe anaemia in children in a Kenyan hospital. Lancet 2002;359:494-495.

7 Lackritz EM, Campbell CC, Ruebush TK 2nd, Hightower AW, Wakube W, Steketee RW, Were JB: Effect of blood transfusion on survival among children in a Kenyan hospital. Lancet 1992;340:524-528.
8 Lackritz EM, Hightower AW, Zucker JR, Ruebush TK 2nd, Onudi CO, Steketee RW, Were JB, Patrick E, Campbell CC: Longitudinal evaluation of severely anemic children in Kenya: the effect of transfusion on mortality and hematologic recovery. Aids 1997;11: 1487-1497.

9 Armano R, Gauvin F, Ducruet T, Lacroix J: Determinants of red blood cell transfusions in a pediatric critical care unit: a prospective, descriptive epidemiological study. Crit Care Med 2005;33:2637-2644.

10 Dellinger EP, Anaya DA: Infectious and immunologic consequences of blood transfusion. Crit Care 2004; 8(suppl 2):S18-23.

11 Carson JL, Grossman BJ, Kleinman S, Tinmouth AT, Marques MB, Fung MK, Holcomb JB, Illoh O, Kaplan LJ, Katz LM, Rao SV, Roback JD, Shander A, Tobian AA, Weinstein R, Swinton McLaughlin LG, Djulbegovic B; Clinical Transfusion Medicine Committee of the AABB: Red blood cell transfusion: a clinical practice guideline from the AABB. Ann Intern Med 2012;157: 49-58.

12 Goodman AM, Pollack MM, Patel KM, Luban NL: Pediatric red blood cell transfusions increase resource use. J Pediatr 2003;142:123-127.
13 Hébert PC, Wells G, Blajchman MA, Marshall J, Martin C, Pagliarello G, Tweeddale M, Schweitzer I, Yetisir E; Transfusion Requirements in Critical Care Investigators, Canadian Critical Care Trials Group: A multicenter, randomized, controlled clinical trial of transfusion requirements in critical care. N Engl J Med 1999; 340:409-417.

14 Laverdière C, Gauvin F, Hébert PC, Infante-Rivard C, Hume H, Toledano BJ, Guertin MC, Lacroix J; Canadian Critical Care Trials Group: Survey on transfusion practices of pediatric intensivists. Pediatr Crit Care Med 2002;3:335-340.

15 Nahum E, Ben-Ari J, Schonfeld T: Blood transfusion policy among European pediatric intensive care physicians. J Intensive Care Med 2004;19:38-43.

16 Lacroix J, Hébert PC, Hutchison JS, Hume HA, Tucci M, Ducruet T, Gauvin F, Collet JP, Toledano BJ, Robillard P, Joffe A, Biarent D, Meert K, Peters MJ; TRIPICU Investigators; Canadian Critical Care Trials Group; Pediatric Acute Lung Injury and Sepsis Investigators Network: Transfusion strategies for patients in pediatric intensive care units. N Engl J Med 2007;356: 1609-1619. 
17 Rouette J, Trottier H, Ducruet T, Beaunoyer M, Lacroix J, Tucci M; Canadian Critical Care Trials Group; PALISI Network: Red blood cell transfusion threshold in postsurgical pediatric intensive care patients: a randomized clinical trial. Ann Surg 2010;251:421-427.

18 Carson JL, Hill S, Carless P, Hébert P, Henry D: Transfusion triggers: a systematic review of the literature. Transfus Med Rev 2002;16:187-199.

19 Bell EF, Strauss RG, Widness JA, Mahoney LT, Mock DM, Seward VJ, Cress GA, Johnson KJ, Kromer IJ, Zimmerman MB: Randomized trial of liberal versus restrictive guidelines for red blood cell transfusion in preterm infants. Pediatrics 2005;115:1685-1691.
20 Kirpalani H, Whyte RK, Andersen C, Asztalos EV, Heddle N, Blajchman MA, Peliowski A, Rios A, LaCorte M, Connelly R, Barrington K, Roberts RS: The Premature Infants in Need of Transfusion (PINT) study: a randomized, controlled trial of a restrictive (low) versus liberal (high) transfusion threshold for extremely low birth weight infants. J Pediatr 2006;149:301-307.

21 Dallman M, Liu X, Harris AD, Hess JR, Edelman BB, Murphy DJ, Netzer G: Changes in transfusion practice over time in the PICU. Pediatr Crit Care Med 2013;14: $843-850$.
22 Gibson BE, Todd A, Roberts I, Pamphilon D, Rodeck C, Bolton-Maggs P, Burbin G, Duguid J, Boulton F Cohen H, Smith N, McClelland DB, Rowley M, Turner G; British Committee for Standards in Haematology Transfusion Task Force: Writing group: transfusion guidelines for neonates and older children. Br J Hematol 2004;124:433-453.

23 Karam O, Tucci M, Ducruet T, Hume HA, Lacroix J, Gauvin F; Canadian Critical Care Trials Group; PALISI Network: Red blood cell transfusion thresholds in pediatric patients with sepsis. Crit Care 2011;12:512-518.

24 Tyrrell CT, Bateman ST: Critically ill children: to transfuse or not to transfuse packed red blood cells, that is the question. Pediatr Crit Care Med 2012;13 204-209. 